\title{
高温溶液法による $\mathrm{NdAl}_{3}\left(\mathrm{BO}_{3}\right)_{4}$ 結晶の育成とフラックスの選択
}

\author{
（1984 年 5 月 28 日 受理） \\ 大石修治* 橋 本巌・楯功
}

\section{1 緒言}

高温溶液法は多種類の化学組成の結晶を融点以下の温度で育成 できるために広く用いられているが, フラックスの選択はいまだ 試行鍇誤的に行なわれている。しかし，最近，著者らは酸化物結 晶育成のフラックス選択を系統的にかつ的確に行ならための選択 指針を提案しだ。

本研究は, レーザー材料として知られている $\mathrm{NdAl}_{3}\left(\mathrm{BO}_{3}\right)_{4}$ 結 晶2) (菱面体晶系, 空間群 $\mathrm{R} 32$ ) ${ }^{3}$ ) を高温溶液法で育成すること 资目的としそそのフラックス選択はさきに提案した選択指針1)に したがった。

\section{2 フラックスの選択}

$\mathrm{NdAl}_{3}\left(\mathrm{BO}_{3}\right)_{4}$ についての基礎情報はつぎのようである。 融点: $\mathrm{NdAl}_{3}\left(\mathrm{BO}_{3}\right)_{4}, 1170^{\circ} \mathrm{C}$ (分解溶融) $\left.)^{4}\right), \mathrm{Nd}_{2} \mathrm{O}_{3}, 2212 \pm 30$ $\left.{ }^{\circ} \mathrm{C}^{5)}, \mathrm{Al}_{2} \mathrm{O}_{3} 2050^{\circ} \mathrm{C}^{6)}, \mathrm{B}_{2} \mathrm{O}_{3} 460^{\circ} \mathrm{C}^{7}\right)$

複酸化物の結晶育成のフラックスの選択指針1)にしたがうと, まず, $\mathrm{B}_{2} \mathrm{O}_{3}$ がフラックスとして選ばれる。しかし， $\mathrm{B}_{2} \mathrm{O}_{3}$ は粘度 が高いので, 絧目修飾イオンの $\mathrm{Ba}^{2+}$ を添加する。 $\mathrm{B}^{2+}$ のイオ ン半径 $\left.(1.35 \AA)^{8}\right)$ は $\mathrm{Nd}^{3+}$ および $\mathrm{Al}^{3+}$ のそれら（それぞれ， $0.983 \AA$ および $0.535 \AA)^{8)}$ よりも大きいため, 目的結晶中の $\mathrm{Nd}^{3+}$ や $\mathrm{Al}^{3+}$ が $\mathrm{Ba}^{2+}$ によって置換される可能性は低い。 $\mathrm{BaO}-\mathrm{B}_{2} \mathrm{O}_{3}$ 二成分系においては, 低い融点 $\left(910^{\circ} \mathrm{C}\right)^{9)}$ をもつ化合物 $\mathrm{BaB}_{4} \mathrm{O}_{7}$

信州大学工学部工業化学科, 380 長野市若里

1) 大石修治, 楯 功, 平野真一, 中 重治, 日化, 1984, 685.

2) たとえば, G. Huber, “Current Topics in Materials Science, Vol. 4", ed. E. Kaldis, North-Holland Publishing Company, Amsterdam (1980) p. 1.

3) H. Y-P. Hong, K. Dwight, Mater. Res. Bull., 9, 1661 (1974).

4) F. Auzel, "The Rare Earths in Modern Science and Technology, Vol.2", ed. G. J. McCarthy, J. J. Rhyne, H. B. Silber, Plenum Press, New York (1980) p. 619.

5）サムソ, フ監修, 遠藤敬一訳, “最新酸化物便覧一物理的 化学的性質一”, 日・ソ通信社（1979） p. 61 .

6) R.S. Roth, T. Negas, L.P. Cook, "Phase Diagrams for Ceramists, Vol. IV", The American Ceramic Society (1981) p. 117.

7）日本化学会編, “化学便覧, 基礎編”, 改訂 2 版, 丸善(1975) p. 85.

8) R. D. Shannon, Acta Crystallogr., Sect. A, 32, 751 (1976).

9) E. M. Levin, C. R. Robbins, H. F. McMurdie, "Phase Diagrams for Ceramists", The American Ceramic Society (1964) p. 97.
が適当なフラックスであると考えられる。

\section{3 実 験 方 法}

出発原料怰市販試薬の $\mathrm{Nd}_{2} \mathrm{O}_{3}$ (99. $9 \%$ ), $\mathrm{Al}_{2} \mathrm{O}_{3}$ (特級), $\mathrm{B}_{2} \mathrm{O}_{3}$ (特級) および $\mathrm{BaCO}_{3}$ (特級) である。これらを所定の化学組成 に乾式混合した調合物（35～50 g) を容量 $30 \mathrm{~cm}^{3}$ の白金るつぼ に入れ，PID 制御で $1150^{\circ} \mathrm{C}$ まで加熱し，10 時間保持したのち, $5^{\circ} \mathrm{C} / \mathrm{h}$ の冷却速度で $600^{\circ} \mathrm{C}$ まで徐冷し, 以後室温まで放冷した。 るつぼ内で固化したフラックスは温希硝酸で溶解除去して結晶を 取りだした。

得られた結晶に若干の検討を加えた。

\section{4. 実験結果と考察}

結晶育成実験に用いた調合物の化学組成とその組成点における 結晶生成の有無を図 1 に示す。実験番号 2〜8 の場合に青紫色透 明の結晶が生成した。その結晶の化学組成は, X 線粉末回折法に よると， $\mathrm{NdAl}_{3}\left(\mathrm{BO}_{3}\right)_{4}$ であった ${ }^{10)}$ 。本実験条件下において生成

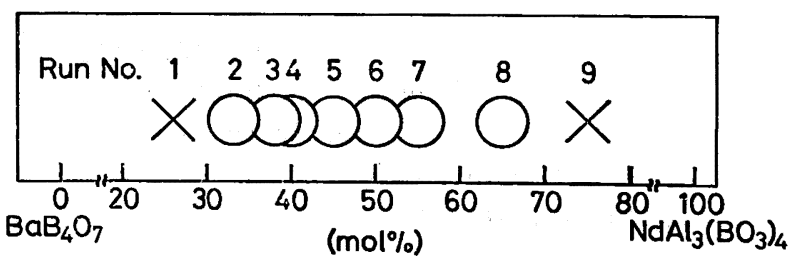

Fig. 1 Mixture compositions in the pseudobinary system $\mathrm{NdAl}_{3}\left(\mathrm{BO}_{3}\right)_{4}-\mathrm{BaB}_{4} \mathrm{O}_{7}$ used in this study

$\mathrm{O}:$ Formation of $\mathrm{NdAl}_{3}\left(\mathrm{BO}_{3}\right)_{4}$ crystal $X$ : No formation of crystal

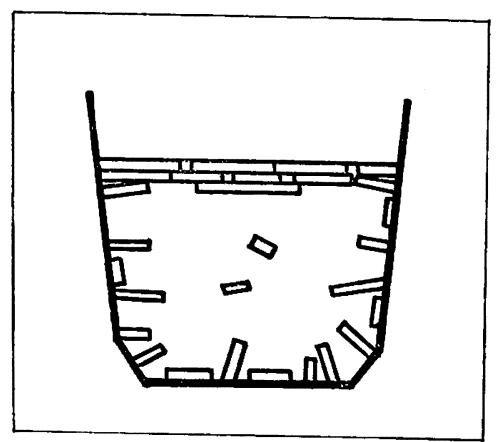

Fig. 2 Schematic arrangement of grown $\mathrm{NdAl}_{3}\left(\mathrm{BO}_{3}\right)_{4}$ crystals in crucible

10) JCPDS カード 18-42. 
した最大結晶の大きさは $7.1 \times 1.5 \times 0.7 \mathrm{~mm}$ であった（実験番号 5 )。

結晶の晶出状況を図 2 に示す。結晶は, 高温溶液の表面付近, るつぼの側壁および底部に主として生成した。少数の結晶は溶液 内部に生成した。るつぼの側壁と底部あるいは溶液内部に生成し た結晶は, 結晶面がよく発達し, 透明であった。一方, 溶液の表 面付近に密集して生成した結晶は，結晶面があれ，不透明である 場合があった。これはフラックスの蒸発（5１5 wt\%）に基づく 急速で不安定な結晶成長のためであろう。

生成した $\mathrm{NdAl}_{3}\left(\mathrm{BO}_{3}\right)_{4}$ 結晶の一例を図 3 に示す。結晶の形態 は $c$ 軸方向に伸びた六角柱であった。

ピクノメーター法 $\left(20.0 \pm 0.5^{\circ} \mathrm{C}\right)$ によると, 結晶の密度は 4.17 $\pm 0.02 \mathrm{~g} / \mathrm{cm}^{3}$ であり, 文献值 $\left.4.161 \mathrm{~g} / \mathrm{cm}^{310}\right)$ とよく一致した。 また，示差熱分析法（基準物質 $\alpha-\mathrm{Al}_{2} \mathrm{O}_{3}$, 昇温速度 $10^{\circ} \mathrm{C} / \mathrm{min}$ ) によると, 結晶の分解溶融点は $1175 \pm 10^{\circ} \mathrm{C}$ であり, 文献値 1170 ${ }^{\circ} \mathbf{C}^{4)}$ とよく一致した。

以上のように, $\mathrm{BaB}_{4} \mathrm{O}_{7}$ フラックスから青紫色透明で六角柱状 の $\mathrm{NdAl}_{3}\left(\mathrm{BO}_{3}\right)_{4}$ 結晶が生成し，選択指針に基づいて選択した

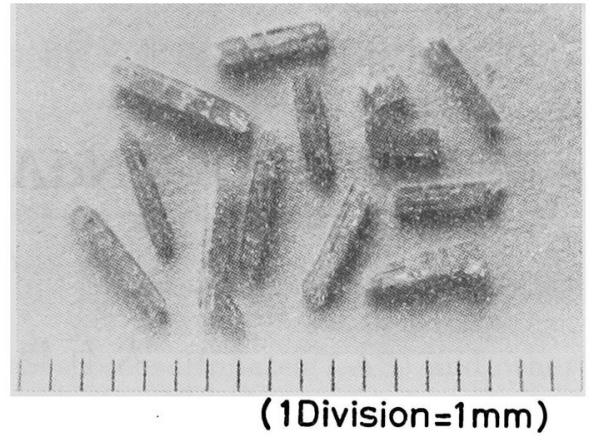

Fig. $3 \mathrm{NdAl}_{3}\left(\mathrm{BO}_{3}\right)_{4}$ crystals grown in $\mathrm{BaB}_{4} \mathrm{O}_{7}$ flux (Run No. 5)

$\mathrm{BaB}_{4} \mathrm{O}_{7}$ は $\mathrm{NdAl}_{3}\left(\mathrm{BO}_{3}\right)_{4}$ 結晶の育成に有効なフラックスである ことが明らかになった。

終りに, フラックスの選択について有益なご示唆をいただいた 名古屋大学工学部中 重治教授批よび平野真一教授に深く感謝い たします。

\title{
Growth of $\mathrm{NdAl}_{3}\left(\mathrm{BO}_{3}\right)_{4}$ Crystals from High-temperature Solution and Choice of Flux
}

\author{
Shuji Oishi*, Iwao Hashimoto and Isao Tate \\ Department of Industrial Chemistry, Faculty of Engineering, \\ Shinshu University; Wakasato, Nagano-shi 380 Japan
}

For the growth of $\mathrm{NdAl}_{3}\left(\mathrm{BO}_{3}\right)_{4}$ crystals, $\mathrm{BaB}_{4} \mathrm{O}_{7}$ was chosen as a flux on the basis of the guide proposed by the authors.

$\mathrm{NdAl}_{3}\left(\mathrm{BO}_{3}\right)_{4}$ crystals were grown by slow cooling of $\mathrm{BaB}_{4} \mathrm{O}_{7}$ flux in which $\mathrm{Nd}_{2} \mathrm{O}_{3}, \mathrm{Al}_{2} \mathrm{O}_{3}$ and $\mathrm{B}_{2} \mathrm{O}_{3}$ were dissolved as solutes. The growth was conducted by heating mixtures at $1150^{\circ} \mathrm{C}$ for $10 \mathrm{~h}$ followed by cooling to $600^{\circ} \mathrm{C}$ at a rate of $5^{\circ} \mathrm{C} / \mathrm{h}$. Crystals grown in $\mathrm{BaB}_{4} \mathrm{O}_{7}$ flux were hexagonal rod in shape, up to $7.1 \times 1.5 \times 0.7 \mathrm{~mm}$ in size, bluish purple in color and transparent. It was shown that the flux chosen was suitable for the growth of objective crystals. 